\title{
Spectrophotometric methods for the simultaneous determination of paracetamol and dantrolene sodium in pharmaceutical dosage form
}

\author{
Ramzia Ismail El-Bagary a, Ehab Farouk Elkady a, Marwa Ahmed Hegazi b,* and Nour Eldin Amin b \\ a Pharmaceutical Chemistry Department, Faculty of Pharmacy, Cairo University, Cairo 11562, Egypt \\ b Drug Radiation Research Department, National Centre for Radiation Research and Technology, Atomic Energy Authority, Nasr City, Cairo 11787, Egypt \\ *Corresponding author at: Drug Radiation Research Department, National Centre for Radiation Research and Technology, Atomic Energy Authority, Nasr City, \\ Cairo 11787, Egypt. \\ Tel.: +20.106.2888118. Fax: +20.2.26173889. E-mail address: marwa.a.hegazi@hotmail.com (M.A. Hegazi).
}

\section{ARTICLE INFORMATION}

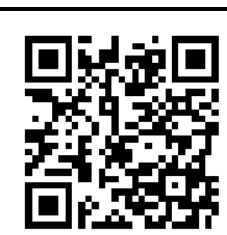

DOI: $10.5155 /$ eurjchem.5.1.96-100.865

Received: 03 July 2013

Received in revised form: 23 August 2013

Accepted: 21 September 2013

Online: 31 March 2014

\section{KEYWORDS}

\section{Dosage form}

Paracetamol

Dantrolene sodium

First derivative ratio

Spectrophotometric method

Simultaneous determination

\section{Introduction}

Paracetamol (PAR); $N$-acetyl- $p$-aminophenol; (Figure 1a) is an analgesic, antipyretic and weak anti-inflammatory drug [1]. Dantrolene sodium (DAS); 1-[5-(4-nitrophenyl)furfurylidene amino]imidazolidine-2,4-dione sodium salt (Figure 1b) is a muscle relaxant with a direct action on skeletal muscles [1]. DAS uncouples muscular contraction from excitation, probably by interfering with the release of calcium from the sarcoplasmic reticulum [1]. Most of the drugs used for treatment of skeletal muscle disorders are combined with analgesics such as PAR. PAR and DAS are formulated as capsule in the ratio of 12:1. This combination is used for myalgia, sprains and skeletal muscle spasms due to neurological disorder.

Several methods have been reported for the determination of PAR either alone [2-4], or with its metabolites in biological fluids [5-7], or in combination with other drugs [8-12]. DAS was also determined either alone [13] or in presence of its metabolites and impurities $[14,15]$ or in biological fluids $[16,17]$. Literature search revealed only one high performance liquid chromatographic method with UV detection (HPLC-UV) for the simultaneous determination of PAR and DAS in dosage form [18]. Thus, the aim of this work was to develop and validate spectrophotometric methods for the determination of PAR and DAS in combination without sample pretreatment.<smiles>CC(=O)Nc1ccc(O)cc1</smiles>

(a)<smiles>O=C1CN(/N=C/c2ccc(-c3ccc([N+](=O)[O-])cc3)o2)C(O)=N1</smiles>

(b)

Figure 1. Chemical structures of paracetamol (a) and dantrolene sodium (b).

Among various techniques, spectrophotometric methods remain the simplest, fastest and less expensive for the determination of drug mixtures [19-21]. Direct UV-absorbance measurement (zero order) is subject to interference from degradation products and/or excipients. Therefore, derivative spectrophotometry has been applied to eliminate such interference. 
Table 1. Results obtained for the determination of dantrolene sodium by zero order method and paracetamol by ${ }^{1} \mathrm{D}$ and ${ }^{1} \mathrm{DD}$ methods in laboratory prepared mixtures.

\begin{tabular}{|c|c|c|c|c|c|}
\hline \multirow[t]{2}{*}{ Parameters } & \multicolumn{2}{|c|}{ Ratio used } & \multicolumn{3}{|l|}{ Amount recovered \% } \\
\hline & DAS & PAR & Zero order method & 1D method & 1DD method \\
\hline & 1 & 12 & 101.86 & 100.77 & 100.27 \\
\hline & 1 & 12 & 99.71 & 98.53 & 98.06 \\
\hline & 1 & 11 & 99.23 & 101.55 & 101.18 \\
\hline & 1 & 10 & 99.36 & 100.70 & 99.84 \\
\hline & 1 & 8 & 100.79 & 100.16 & 99.35 \\
\hline Mean (\%) & & & 100.19 & 100.34 & 99.74 \\
\hline S.D. \pm & & & 1.000 & 1.007 & 1.030 \\
\hline S.E. \pm & & & 0.44 & 0.45 & 0.46 \\
\hline R.S.D. (\%) & & & 0.9984 & 1.0030 & 1.0300 \\
\hline
\end{tabular}

Two methods were developed and validated: first derivative $\left({ }^{1} \mathrm{D}\right)$ and first derivative ratio ( $\left.{ }^{1} \mathrm{DD}\right)$ spectrophotometric methods to enhance the resolution of overlapping bands. The derivative spectrophotometry can be used for simultaneous determination of many drugs, it is applied by selecting a wavelength where the compound to be determined has a reasonable value while the contribution of the other compound is almost zero [19-21].

\section{Experimental}

\subsection{Instrumentation}

A Jenway 6800 double beam ultraviolet/visible spectrometer (Keison International Ltd., U.K), connected to an IBM compatible computer using $1 \mathrm{~cm}$ quartz cell and supported with Jenway flight deck software was used.

\subsection{Reagents and reference samples}

Pharmaceutical grade of PAR (certified to contain 99.80\%) and DAS (certified to contain 100.1\%) and DantrelexCompound ${ }^{\circledR}$ capsules nominally containing $300 \mathrm{mg}$ of PAR and 25 mg DAS per capsule (Batch no. 110201A) were kindly provided by Chemipharm Pharm. Ind. (6th October city, Egypt). Solvents used are tetrahydrofuran HPLC grade (Tedia Company, Fairfield, United States), glacial acetic acid and absolute ethanol analytical grade (El-Nasr Pharmaceutical Chemicals Company, Gesr El Suez, Cairo, Egypt.).

The standard stock solutions of PAR and DAS $(100 \mu \mathrm{g} / \mathrm{mL})$ were prepared by separately dissolving $10 \mathrm{mg}$ of each drug in $100 \mathrm{~mL}$ of the solvent mixture which was further diluted by absolute ethanol to reach the required serial dilutions. The solvent mixture was prepared by mixing $10 \mathrm{~mL}$ of tetrahydrofuran, $2 \mathrm{~mL}$ glacial acetic acid and $88 \mathrm{~mL}$ absolute ethanol.

\subsection{General procedures and calibration}

\subsubsection{Zero order spectrophotometric method}

Aliquots from DAS standard stock solution equivalent to 10-200 $\mu$ g were accurately measured and transferred into a series of $10 \mathrm{~mL}$ volumetric flasks and then completed to volumes with absolute ethanol. For each solution, the zero order absorption spectra was recorded at $379.0 \mathrm{~nm}$ against absolute ethanol as a blank, and then plotted against its corresponding concentration. The regression equation was computed.

\subsection{2. ${ }^{1 D}$ method}

Aliquots from PAR stock standard solutions equivalent to 15-200 $\mu \mathrm{g}$ were accurately measured and transferred into a series of $10 \mathrm{~mL}$ volumetric flasks and then completed to volumes with absolute ethanol. For each solution, the zero order absorption spectrum was recorded against absolute ethanol as a blank, and then ${ }^{1} \mathrm{D}$ spectrum were computed applying scaling factor of 100 . The amplitudes at $265.5 \mathrm{~nm}$ were measured and plotted against their corresponding concentrations. The regression equation was computed.

\subsection{3. ${ }^{1 D D}$ method}

The previously scanned zero order absorption spectra of PAR were divided by the spectrum of DAS $(2 \mu \mathrm{g} / \mathrm{mL})$ which was the chosen divisor. ${ }^{1 D}$ of the obtained ratio spectra was computed. The amplitudes at $265.0 \mathrm{~nm}$ were measured and plotted against their corresponding concentrations. The regression equation was computed.

\subsection{Assay of laboratory-prepared mixtures}

Laboratory-prepared mixtures were prepared using known concentration of DAS and PAR in the ratio of 1:12, 1:10, 1:11 and 1:8, respectively (Table 1 ). The absorption spectra of the laboratory prepared mixtures of DAS and PAR were recorded against absolute ethanol as a blank. The zero order absorption spectra at $379.0 \mathrm{~nm}$ were used for the direct determination of DAS. On the other hand, the ${ }^{1} \mathrm{D}$ and the ${ }^{1} \mathrm{DD}$ methods were applied for the determination of PAR. The amplitudes of 1D spectrum of the laboratory prepared mixtures were measured at $265.5 \mathrm{~nm}$. For the ${ }^{1} \mathrm{DD}$ method, the previously scanned zero order absorption spectra for the laboratory prepared mixtures were divided by the spectrum of DAS $(2 \mu \mathrm{g} / \mathrm{mL})$. The amplitudes were measured at $265.0 \mathrm{~nm}$. The concentrations of DAS and PAR were calculated from their corresponding regression equations (Table 1 ).

\subsection{Assay of Dantrelex compound $®$ capsules}

Twenty capsules were emptied, weighted and finely powdered. An accurate amount of the powder equivalent to 10 $\mathrm{mg}$ of DAS and $10 \mathrm{mg}$ of PAR were weighed separately, each transferred into a $100 \mathrm{~mL}$ calibrated flask, dissolved in solvent mixture, sonicated for 30 min then completed to volume with the solvent mixture. The solution was filtered and diluted with absolute ethanol to the required concentration for each experiment. The procedure was continued as mentioned before under general procedures and calibration. The concentrations of DAS and PAR were calculated from their corresponding regression equations (Table 2 ).

\section{Results and discussion}

The development of spectrophotometric methods for the determination of PAR in binary mixture with DAS was of interest as there were no spectrophotometric methods have been reported for this mixture.

\subsection{Optimization of conditions for spectrophotometric methods}


Table 2. Results obtained for the determination of dantrolene sodium by zero order method and paracetamol by ${ }^{1} \mathrm{D}$ and ${ }^{1} \mathrm{DD}$ methods in dosage form (dantrelex compound capsule) using standard addition technique.

\begin{tabular}{|c|c|c|c|c|c|c|c|c|c|c|}
\hline \multirow[t]{2}{*}{ Parameters } & \multicolumn{2}{|c|}{$\begin{array}{l}\text { Amount taken } \\
(\mu \mathrm{g} / \mathrm{mL})^{\mathrm{a}}\end{array}$} & \multicolumn{2}{|c|}{$\begin{array}{l}\text { Amount recovered (\%) } \\
\text { by zero order method }\end{array}$} & \multicolumn{2}{|c|}{$\begin{array}{l}\text { Amount taken }(\mu \mathrm{g} / \mathrm{mL}) \\
\mathrm{b}\end{array}$} & \multicolumn{2}{|c|}{$\begin{array}{l}\text { Amount recovered (\%) } \\
\text { by }{ }^{1 D} \text { method }\end{array}$} & \multicolumn{2}{|c|}{$\begin{array}{l}\text { Amount recovered (\%) } \\
\text { by }{ }^{1 D D} \text { method }\end{array}$} \\
\hline & $\begin{array}{l}\text { Dosage } \\
\text { form }\end{array}$ & $\begin{array}{l}\text { Standard } \\
\text { added }\end{array}$ & $\begin{array}{l}\text { Dosage } \\
\text { form }\end{array}$ & $\begin{array}{l}\text { Standard } \\
\text { added }\end{array}$ & $\begin{array}{l}\text { Dosage } \\
\text { form }\end{array}$ & $\begin{array}{l}\text { Standard } \\
\text { added }\end{array}$ & $\begin{array}{l}\text { Dosage } \\
\text { form }\end{array}$ & $\begin{array}{l}\text { Standard } \\
\text { added }\end{array}$ & $\begin{array}{l}\text { Dosage } \\
\text { form }\end{array}$ & $\begin{array}{l}\text { Standard } \\
\text { added }\end{array}$ \\
\hline & 6 & 3 & 90.91 & 98.50 & 6 & 3 & 102.88 & 99.71 & 102.35 & 99.05 \\
\hline & 6 & 4 & 90.91 & 99.13 & 6 & 4 & 102.88 & 100.55 & 102.35 & 100.23 \\
\hline & 6 & 5 & 90.74 & 99.15 & 6 & 5 & 102.88 & 100.05 & 102.35 & 99.66 \\
\hline & 8 & 6 & 90.52 & 101.28 & 8 & 6 & 103.24 & 100.55 & 102.57 & 100.34 \\
\hline & 8 & 7 & 90.92 & 100.70 & 8 & 7 & 102.92 & 101.98 & 102.57 & 101.10 \\
\hline Mean (\%) & & & 90.80 & 99.75 & & & 102.96 & 100.57 & 102.44 & 100.08 \\
\hline S.D \pm & & & 0.17 & 1.17 & & & 0.15 & 0.86 & 0.11 & 0.76 \\
\hline S.E \pm & & & 0.07 & 0.52 & & & 0.06 & 0.35 & 0.04 & 0.31 \\
\hline R.S.D. (\%) & & & 0.03 & 1.17 & & & 0.15 & 0.86 & 0.11 & 0.76 \\
\hline
\end{tabular}

amount taken of dantrolene sodium $(\mu \mathrm{g} / \mathrm{mL})$

b Amount taken of paracetamol $(\mu \mathrm{g} / \mathrm{mL})$.

Table 3. Results obtained for the determination of dantrolene sodium by zero order method and for the determination of paracetamol by ${ }^{1} \mathrm{D}$ and ${ }^{1} \mathrm{DD}$ methods.

\begin{tabular}{|c|c|c|c|}
\hline Parameters & Zero order method & 1D method & 1DD method \\
\hline$\lambda_{\max }$ of measurements (nm) & 379.0 & 265.5 & 265.0 \\
\hline Linearity $(\mu \mathrm{g} / \mathrm{mL})$ & $1.0-20.0$ & $1.5-20.0$ & $1.5-20.0$ \\
\hline Regression equation & $\mathrm{C}_{\mu \mathrm{g} / \mathrm{mL}}=0.0696 \mathrm{~A}_{279}-0.0018$ & $\mathrm{H}_{265.5}=0.1989 \mathrm{C}_{\mu \mathrm{g} / \mathrm{mL}}-0.0178$ & $\mathrm{H}_{265}=0.0265 \mathrm{C}_{\mu \mathrm{g} / \mathrm{mL}}-0.0017$ \\
\hline Regression coefficient $\left(r^{2}\right)$ & 0.9999 & 0.9999 & 0.9999 \\
\hline $\mathrm{LOD}(\mu \mathrm{g} / \mathrm{mL})$ & 0.26 & 0.28 & 0.25 \\
\hline $\mathrm{LOQ}(\mu \mathrm{g} / \mathrm{mL})$ & 0.89 & 0.96 & 0.86 \\
\hline$S_{b}$ & $1.89 \times 10^{-4}$ & $6.65 \times 10^{-4}$ & $8.9 \times 10^{-5}$ \\
\hline$S_{a}$ & $2.22 \times 10^{-3}$ & $7.809 \times 10^{-3}$ & $1.04 \times 10^{-3}$ \\
\hline Confidence limit of the slope & $0.0696 \pm 4.63 \times 10^{-4}$ & $0.1989 \pm 1.620 \times 10^{-2}$ & $0.0265 \pm 2.10 \times 10^{-4}$ \\
\hline Confidence limit of the intercept & $0.0018 \pm 5.44 \times 10^{-3}$ & $0.0178 \pm 1.913 \times 10^{-2}$ & $0.0017 \pm 2.54 \times 10^{-3}$ \\
\hline Standard error of the estimation & 0.0037 & 0.01211 & 0.00162 \\
\hline Drug in laboratory prepared mixture (\%) & $100.19 \pm 1$ & $100.34 \pm 1.007$ & $99.74 \pm 1.03$ \\
\hline Drug in dosage form (Dantrelex Compound ${ }^{\circledR}$ ) (\%) & $90.8 \pm 0.17$ & $102.96 \pm 0.157$ & $102.44 \pm 0.116$ \\
\hline Drug added (\%) & $99.75 \pm 1.17$ & $100.57 \pm 0.868$ & $100.08 \pm 0.769$ \\
\hline
\end{tabular}

\subsubsection{Zero order method}

DAS could be always determined using the zero order spectrum at $379.0 \mathrm{~nm}$ (Figure 2) without interference from PAR. DAS showed linear correlation between the absorption and their corresponding concentrations in the range of 1-20 $\mu \mathrm{g} / \mathrm{mL}$ (Table 3). The characteristic parameters of the regression equation are given in Table 3.

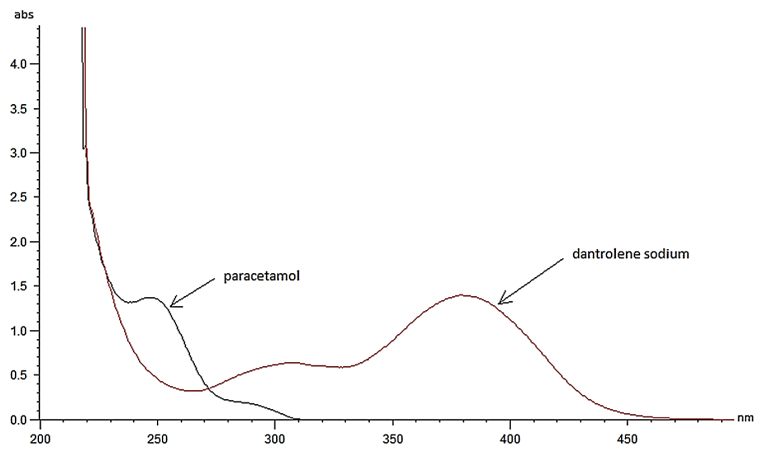

Figure 2. Zero order absorption spectra of dantrolene sodium $(20 \mu \mathrm{g} / \mathrm{mL})$ and paracetamol $(14 \mu \mathrm{g} / \mathrm{mL})$.

\subsection{2. ${ }^{1} D$ and ${ }^{1} D D$ methods}

However, PAR could not be determined by zero order spectrophotometry as its absorption spectrum exhibits overlap with that of DAS (Figure 2). ${ }^{1} \mathrm{D}$ and ${ }^{1} \mathrm{DD}$ methods have been applied to resolve the interferences between the overlapping spectra and to allow for the determination of PAR in the presence of DAS (Figure 3 and 4).

1D technique showed that PAR could be determined by measuring the amplitude values at $265.5 \mathrm{~nm}$ (Figure 3). PAR showed linear correlation between amplitude values and their corresponding concentrations in the range of $1.5-20 \mu \mathrm{g} / \mathrm{mL}$ (Table 3).

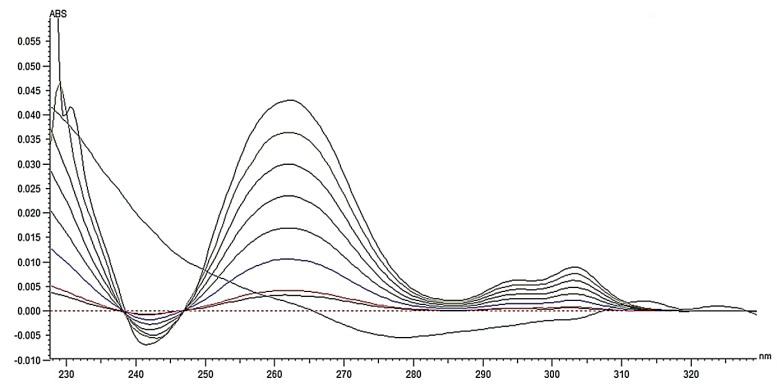

Figure 3. The first derivative spectra of paracetamol $(1.5-20.0 \mu \mathrm{g} / \mathrm{mL})$ at zero crossing wavelength $(265.5 \mathrm{~nm})$.

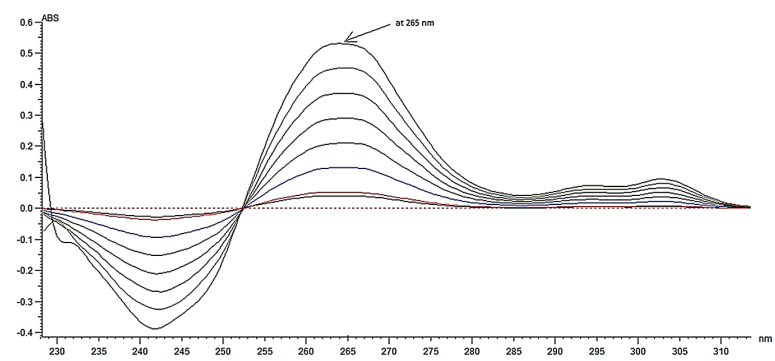

Figure 4. The first derivative ratio spectra (1DD) of paracetamol (1.5-20.0 $\mu \mathrm{g} / \mathrm{mL}$ ) (Divisor: $2 \mu \mathrm{g} / \mathrm{mL}$ dantrolene sodium) at $265.0 \mathrm{~nm}$.

Another method for resolving interferences between PAR and DAS spectra is the ${ }^{1} \mathrm{DD}$ method [19-21]. The zero order absorption spectrum of PAR is recorded, divided by the absorption spectrum of a standard solution of known concentration of DAS $(2 \mu \mathrm{g} / \mathrm{mL})$ and then the ${ }^{1} \mathrm{D}$ spectrum is obtained. 
Table 4. The results obtained of intra-day and inter-day assays of 3 different concentrations of dantrolene sodium by zero order method and paracetamol by ${ }^{1} \mathrm{D}$ and 1DD methods.

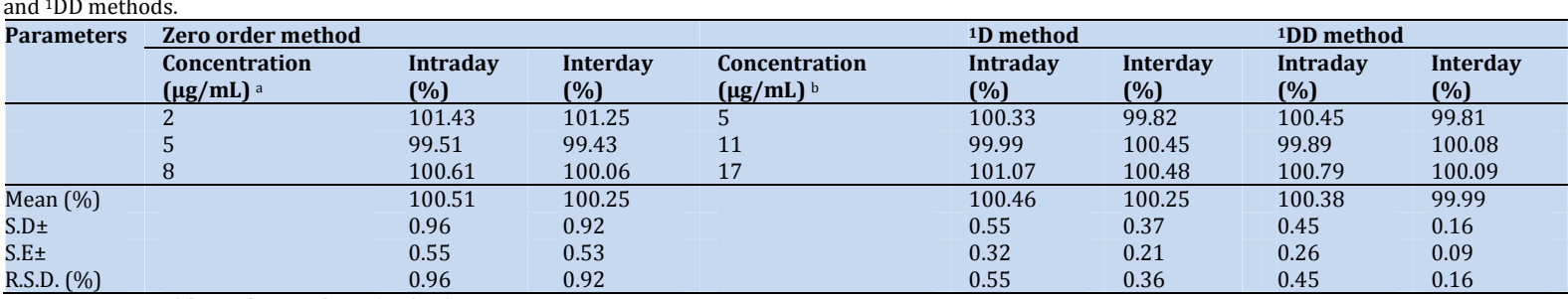

a Concentration of dantrolene sodium $(\mu \mathrm{g} / \mathrm{mL})$

b Concentration of paracetamol $(\mu \mathrm{g} / \mathrm{mL})$.

Table 5. Statistical comparison between the results of the spectrophotometric method and the reference method for the determination of Dantrolene Sodium.

\begin{tabular}{|c|c|c|c|}
\hline Statistical term & Reference method ${ }^{a}$ & Zero order method & Binary mixture with PAR \\
\hline Mean (\%) & 99.72 & 100.04 & 100.19 \\
\hline S.D. \pm & 1.27 & 0.98 & 1 \\
\hline S.E. \pm & 0.63 & 0.44 & 0.44 \\
\hline R.S.D. (\%) & 1.28 & 0.98 & 0.99 \\
\hline $\mathrm{N}$ & 5 & 5 & 5 \\
\hline V & 1.61 & 0.96 & 1 \\
\hline$t(2.306)^{b}$ & & 0.41 & 0.31 \\
\hline $\mathrm{F}(6.39)^{\mathrm{b}}$ & & 1.67 & 2.27 \\
\hline
\end{tabular}

Referenc

b Figures in parentheses are the theoretical t and F values at $(p=0.05)$.

Table 6. Statistical comparison between the results of the spectrophotometric methods and the refrence method for the determination of Paracetamol.

\begin{tabular}{llllll}
\hline Statistical term & Reference method a & 1D at 265.5 $\mathbf{~ n m}$ & 1DD at 265.0 $\mathbf{~ n m}$ & 1D of Binary mixture with DAS & 1DD of Binary mixture with DAS \\
\hline Mean (\%) & 100.16 & 100.24 & 99.65 & 100.34 & 99.74 \\
S.D. & 0.99 & 1.04 & 1.08 & 1.007 & 1.03 \\
S.E. & 0.44 & 0.46 & 0.48 & 0.45 & 0.46 \\
R.S.D. (\%) & 0.98 & 1.04 & 1.09 & 1.003 & 1.03 \\
N & 5 & 5 & 5 & 5 & 5 \\
V & 0.98 & 1.08 & 1.16 & 1.01 & 1.06 \\
t $(2.306)^{\text {b }}$ & & 1.25 & 0.78 & 0.286 & 0.6598 \\
F (6.39) & & 1.1 & 1.18 & 1.03 & 1.08 \\
\hline
\end{tabular}

a Reference method: aliquots of standard solutions in distilled water containing 1.5-20.0 $\mu \mathrm{g} / \mathrm{mL}$ PAR were measured at $249 \mathrm{~nm}$ using water as a blank

$\mathrm{b}$ Figures in parentheses are the theoretical t and F values at $(p=0.05)$.

In order to optimize the ${ }^{1} \mathrm{DD}$ method that was developed, the influence of different variables was studied such as the divisor concentration, smoothing factor and the wavelength of measurement.

The exact choice of these parameters was of great importance, so ten different concentrations of DAS $(1,2,4, \ldots$, and $20 \mu \mathrm{g} / \mathrm{mL}$ ) were tried as divisors. It was found that the minimum noise and the better selectivity were obtained upon using $2 \mu \mathrm{g} / \mathrm{mL}$ of DAS spectrum as a divisor and smoothing factor 15 and measuring the amplitudes at $265.0 \mathrm{~nm}$ (Figure 4). PAR showed linear correlation between the amplitudes values and their corresponding concentrations in the range of 1.5-20 $\mu \mathrm{g} / \mathrm{mL}$. The characteristic parameters of the regression equation of the ${ }^{1} \mathrm{DD}$ for the determination of PAR are given in Table 3 .

\subsection{Validation of spectrophotometric methods}

Standard calibration curves were performed by measuring the response of serial dilutions of each of the two drugs separately and applying the previously suggested procedures. The calibration curves linearity was validated by the correlation coefficients good values (Table 3). Table 3 reveals the correlation coefficients along with standard deviation of the slope $\left(\mathrm{S}_{\mathrm{b}}\right)$ and that of intercept $\left(\mathrm{S}_{\mathrm{a}}\right)$. The regression equations of the calibration curves were utilized for the determination of concentrations of DAS and PAR in laboratory prepared mixtures (Table 1) and capsules (Table 2). The accuracy and the reproducibility of the proposed methods were evaluated by using laboratory prepared solutions of different concentrations of the suggested drugs separately and by determining the concentrations in the dosage form. The standard addition technique was used to validate the accuracy of the procedures for the estimation of capsules (Table 2). The precision was evaluated by performing intra-day and inter-day assays on 3 different concentrations of DAS and PAR separately using the suggested spectrophotometric methods (Table 4). The results obtained were accurate and precise (Table 4).

\subsection{Limit of Detection and limit of quantification}

According to the ICH recommendations [22,23], the approach based on the S.D. of the response and the slope was used for determining the limit of detection and limit of quantification (Table 3).

\subsection{Statistical analysis}

A statistical analysis of the obtained results by the proposed methods for the determination of DAS and PAR and those obtained by the reference methods was carried out by using "SPSS statistical package version 11". The one way ANOVA (F-test) at $p=0.05$ was performed to test the significant difference between groups as shown in (Table 5 and 6). No significant difference was found among the methods.

\section{Conclusion}

The suggested methods for the simultaneous determination of DAS and PAR show simplicity, precision and accuracy. The ${ }^{1} \mathrm{D}$ and ${ }^{1} \mathrm{DD}$ methods enable the simultaneous quantitation of DAS and PAR either in laboratory prepared mixtures or in pharmaceutical dosage form without sample pretreatment or separation steps. Hence the two proposed methods could be 
used for routine analysis in quality control laboratories for the mentioned drugs where economy and time are essential.

\section{References}

[1]. Sweetman, S. C. Martindale: The Complete Drug Reference, 33 ${ }^{\text {rd }}$ ed., Pharmaceutical Press, London, 2002.

[2]. Bahramipur, H.; Jalali, F. Afr. J. Pharm. Pharmacol. 2012, 6(17), 12981305

[3]. Knochen, M.; Giglio, J.; Reis, B. F. J. Pharmaceut. Biomed. 2003, 33(2), 191-197.

[4]. Van Staden, J. F.; Tsanwani, M. Talanta 2002, 58(6), 1095-1101.

[5]. Hewavitharana, A. K.; Lee, S.; Dawson, P. A.; Markovich, D.; Shaw, P. N. Anal. Biochem. 2008, 374(1), 106-111.

[6]. An, J. H.; Lee, H. J.; Jung, B. H. Biomed. Chromatogr. 2012, 26(12), 15961604.

[7]. Tan, Q. Y.; Zhu, R. H.; Li, H. D.; Wang, F.; Yan, M.; Dai, L. B. J. Chromatogr. B 2012, 893-894, 162-167.

[8]. Khan, H.; Ali, M.; Ahmad, S.; Ahmad, N.; Ahuja, A.; Baboota, S.; Ali, J. J. Liq. Chromatog. R. T. 2012, 35(1), 109-128.

[9]. Alves, J. C. L.; Poppi, R. J. Anal. Chim. Acta 2009, 642(1-2), 212-216.

[10]. Hassan, W. S. Am. J. Appl. Sci. 2008, 5, 1005-1012.

[11]. Ing-Lorenzini, K. R.; Desmeules, J. A.; Besson, M.; Veuthey, J. L.; Dayer, P.; Daali, Y. J. Chromatog. A 2009, 1216(18), 3851-3856.

[12]. Arayne, M. S.; Sultana, N.; Siddiqui, F. A. J. Chinese Chem. Soc. 2009, 56(1), 169-174

[13]. Saxena, S. J.; Honigberg, I. L.; Stewart, J. T.; Keene, G. R.; Vallner, J. J. J. Pharm. Sci. 1977, 66(2), 286-288.

[14]. Cox, P. L.; Heotis, J. P.; Polin, D.; Rose, G. M. J. Pharm. Sci. 1969, 58(8), 987-989.

[15]. Tawakkul, M. A.; Faustino, P. J.; Sayeed, V. A.; Khan, M. A.; Khan, S. R. Clin. Res. Regul. Aff. 2010, 27(1), 21-29.

[16]. Wuis, E. W.; Grutters, A. C. L. M.; Vree, T. B.; Van Der Kleyn, E. J. Chromatog. B 1982, 231(2), 401-409.

[17]. Conklin, J. D.; Sobers, R. J. J. Pharm. Sci. 1973, 62(6), 1024-1025.

[18]. Hadad, G. M.; Emara, S.; Mahmoud, W. M. Talanta 2009, 79(5), 13601367.

[19]. Altınoz, S.; Toptan, S. J. Food Compos. Anal. 2003, 16(4), 517-530.

[20]. Bebawy, L. I.; Abbas, S. S.; Fattah, L. A.; Refaat, H. H. Il Farmaco 2005, 60(10), 859-867.

[21]. Hapse, S. A.; Kadaskar, P. T.; Shirsath A. S. Der Pharmacia Lett. 2011 , 3(6), 18-23.

[22]. Samir, A.; Salem, H.; Abdelkawy, M. Bull. Fac. Pharm. Cairo Univ. 2012, 50(2), 121-126

[23]. Da Silva Sangoi, M. Quim. Nova 2010, 33(6), 1330-1334. 